\title{
Draft Constitution of Kurdistan and Intergovernmental Relations in Iraq
}

\author{
Ayman El-Dessouki ${ }^{1}$ \\ ${ }^{1}$ College of Political Science, Cairo University, Egypt
}

\begin{abstract}
The draft constitution of Kurdistan (draft constitution) was ratified by the regional parliament in June 2009. A planned referendum on the draft in the same year was deferred due to a number of disagreements between Baghdad and Erbil and as a result of calls by the US, who persuaded Iraqi Kurdistan (KRI) to wait for a referendum to avoid confrontations with Baghdad (Oettershagen, 2015, p. 22).

There are large discrepancies between the Iraqi constitution of 2005 and the draft constitution over many questions related to the intergovernmental relations (IGR) between the Government of Iraq (GOI) and the Kurdistan Regional Government (KRG). The 2009 draft represented an attempt to reduce the KRG's reliance on the Iraqi constitution and cement the region's autonomy (Schweitzer, 2015). Baghdad refuses to accept this draft as it considers it to be a serious threat to Iraq's unity and an infringement on the Iraqi constitution (El-Dessouki, 2012).

IGR in Iraq are crucial for KRI existence (Gunter, 2011, pp. 137-9). Nonetheless, these relations are far from harmonious and basically conflictual. The KRG and the GOI are locked in a struggle for control over land, wealth and political advantage, which is further exacerbated by opposing notions of national identity. This struggle is, of course, rooted in the history of the land.
\end{abstract}

.KEY WORDS: exactly 5 (no more and no less) keywords separated by comma, Use as many as possible of these words in your main title.

\section{INTRODUCTION}

\section{Research Question:}

Scholarly literature regarding the draft constitution and its effect on IGR in Iraq is not available yet. This paper examines the dynamics of intergovernmental relations (IGR) between the KRG and the GOI from the draft constitution's perspective. Thus, this paper poses the following question as the key problem: How does the draft constitution establish IGR between KRI and the central government of Iraq?

In doing so, the paper examines many issues related to IGR in Iraq, including the distribution of powers

The Second International Scientific Conference of the Department of Law, Faculty of Humanities and Social Sciences (FHSS), Koya University, Under the title:

Towards a Contemporary Constitution for Kurdistan RegionIraq (C2019

27-28 November 2019

Corresponding author's e-mail: ayelde@feps.edu.eg

Copyright @2017 Authors Names: Dr. Ayman El-Dessouki between the federal and regional levels of government, the control and development of hydrocarbon sources, as well as the distribution of their revenues, and the territorial dispute between Baghdad and Erbil. The type of federalism that should be adopted in Iraq and the nature of Kurdistan polity, as envisioned by the draft constitution, will be carefully handled in the paper. The status of Peshmerga and KRI's growing international activism or paradiplomacy, as additional sources of contention between the GOI and the KRG, will be explained in this paper.

\section{Methodology:}

The term 'intergovernmental relations' (IGR) refers to the working connections that tie central governments to subnational units or the processes and institutions through which governments within a political system interact. IGR can include exchanges between central and subnational governments, patterns of interaction (cooperative or conflictual) and structures that channel interaction between the two tiers of governments (Bolleyer, McEwen and Swenden, 2010; de Vicuňa, 2015). Two indicators of IGR are examined, including 
the pattern of IGR (cooperative or confrontational/conflictual pattern) and dynamics and structures of IGR.

The necessary information to tackle the research question will be drawn from a careful study of national constitution and regional draft constitution, the relevant legal documents (laws, decrees, and executive orders) concerning IGR, official central and regional government policy documents and websites, official statements, relevant news articles, and secondary literature. Based on a longitudinal within-case analysis, this paper will investigate how the draft constitution of KR defines IGR between the KRG and the GOI, and the Kurdish constitutional perspective differ from the Iraqi constitution's vision on IGR.

\section{Distribution of Powers between the Federal and Regional Governments:}

The draft constitution adopts the distribution of powers approved by the Iraqi constitution, but the former stresses more on the autonomy and de-facto independence of KRI. The draft constitution does acknowledge the Iraqi constitution's superiority, though the language used in some articles questions this authority. Article 3 of the draft constitution, as it will be illustrated later, establishes the authority of the KRG and its constitution. Thereby, it authenticates sovereignty of the constitution of Iraqi Kurdistan, apart from exclusive federal jurisdiction.

Iraqi constitution provides for a federal structure consisting of governorates that can, at their discretion, combine to form regions with broader powers (IRQ Const. 2005, art. 116, 119). It clearly and strongly empowers regions over the central government, in part to prevent the excessive centralization that had previously led to oppression and suffering for the people of Iraq (Sadoon, 2017, p. 392).

Despite the historically adversarial relations between the central government and Kurds, the Iraqi constitution (art. $117 \S 1$ ) recognizes KRI as a legal region, making it the only federal region explicitly mentioned in its provisions. This acknowledgment appears to be either the result of Kurdish influence during the drafting of the Iraqi constitution or an incentive to encourage Kurdish participation in a unified Iraqi government (Doherty, 2011, pp. 98, 99). IKI remains the only federal region in Iraq to date, after unsuccessful attempts at the formation of regions in Basra, Salah ad-Din, Anbar and Diyala (SIGIR, 2012, p. 5).

Articles 1 of the draft constitution explicitly acknowledges the integrity of KRI within federal Iraq as a region. Nevertheless, the second sentence proclaims KRI to be a 'democratic republic', thereby reaffirming its de-facto independence and autonomy from Iraq (Oettershagen, 2015, pp. 22-3).

In fact, the draft constitution asserts the right of the
Kurdish people to self-determination; the full Wilsonian ideal. Thus, the KRI will remain part of the Iraqi federation, but only 'as long as Iraq abides' by certain rules. These rules are related to the GOI's commitment to "the federal, democratic, parliamentary and pluralistic system, and human rights" (Draft Const., 2009, art. 7). In other words, the region reserves the right to leave the federation if the GOI either departs from the federal model or abandons the constitutional principles of democracy and human rights (O'Sullivan, 2009; Parker, 2010). While not acknowledged by the Iraqi constitution in itself, Article 7 demonstrates the willingness of KRI to become a legal independent entity, if federal Iraq does not cherish the disciplines aforementioned. Thereby, this can be seen as political leverage which can be acted upon so that Iraq allows Kurdistan its federal autonomy and disintegrates from political processes within Iraqi Kurdistan. Thus, this Article 7 is a warning of secession to Iraq. In practice, Kurdish leaders have made such a warning on several occasions (El-Dessouki, 2013; Hiltermann, 2012). This warning was put into action as evidenced by the 25 September 2017 independence referendum held in the entity.

The Iraqi constitution (art. 143) delineates Kurdistan's borders as encompassing the territory it occupied on 19 March 2003, before the US-led invasion of Iraq. However, what constitutional borders of the region exactly mean is controversial. Do they only include the three governorates of Erbil, Dohuk and Sulaimania or even parts of Nineva, Kirkuk and Diyala governorates? Put differently, there is no de jure definition of the KR, and the 'green line' dividing the KRI from the rest of Iraq is the de facto border. However, the draft constitution (art. $2 \S 1$ ) includes references to KRI's administrative boundaries containing disputed territories outside the 'green line' in Kirkuk, Nineveh, and Diyala. This is contradicted with the draft measure's reliance on article 140 of the Iraqi constitution to determine the final political borders of the region, as it will be illustrated later.

The Iraqi constitution (preamble, art. 4, 141) acknowledges the legitimacy of Kurdish identity and recognizes Kurdish as one of two national/official languages. An important cultural aspect of the draft constitution (art. 14, § 1) is the recognition of both Kurdish and Arabic as official languages. In addition, the Turkoman and Syriac languages are official in those administrative units where people form the majority in speaking in the Turkoman and Syriac languages (art. 14, $\S 2)$.

Interestingly, the draft constitution places much less emphasis on Islamic identity when contrasted against the Iraqi constitution. Whereas the latter (art. 2) places Islam as the official religion of Iraq and a foundation source of legislation, Islam is not even addressed in the 
draft constitution until Article 7, which recognizes the Muslim identity of the majority of the people of Kurdistan and the principles of Islamic Shari'a as one of the sources of legislation.

The Iraqi constitution (art. 110) identifies certain issues as falling exclusively within the purview of the federal government. These include constitutional issues (e.g. federal institutions, federal elections), foreign affairs (including foreign policy making, diplomatic representation and international treaties), defense and national security, fiscal and monetary policy (and related matters such as inter-regional commerce), home affairs (e.g. citizenship, naturalization, residency, political asylum, population statistics and census, telecommunications and mail), standards and weights, and the supply of water from outside Iraq.

All other matters come under the jurisdiction of regions and governorates (IRQ Const., 2005, art. 115). This Article can be considered as one of the most important clauses in the Iraqi constitution stipulating consolidation of the KRI (Sadoon, 2017, p. 334). The region has 'residual authority', i.e., it is given exclusive right to legislate on policy areas not specifically assigned in Iraqi constitution (El-Dessouki, 2013). In addition, there are other clearly enunciated rights reserved by the Iraqi constitution for the regions. Regions are given the right to adopt separate constitutions provided their provisions do not contradict the federal constitution (art. $120,121)$. They also have the right to exercise executive, legislative and judicial powers in accordance with their respective constitutions. Regions are allocated a share of national revenues sufficient to discharge their responsibilities based on their resources, needs and population percentages (art. 121, §3).

The draft constitution reserves exclusive right to legislate on many specific policy areas to KRI. It enables the KRG to carry out sovereign functions such as collecting taxes (Hadj, 2015, p. 519). The KRG has the power to raise its own taxes separate to the federal tax system and keeps all taxes raised within its territory (art. 13). It controls the region's borders with neighboring countries and collects customs (Sowell, 2014). The draft constitution consolidates the KRI's status as a quasi-state or a de-facto state (Natali, 2010; Sadoon, 2017).

There is a very small overlap between the mandates of the federal and regional governments, including the administration of antiquities, antiquity sites, traditional constructions, manuscripts, coins and customs. Other shared powers cover the regulation of electrical power energy, environmental policy, planning, public health and education, and internal water resources policy (IRQ Const., 2005, art. 114; El-Dessouki, 2013).

In case of a contradiction between regional and national legislation with respect to matters outside the exclusive powers of the federal government, the Iraqi constitution (art. 166 § 2) stipulates that regions have the power to amend the application of national laws. The regions are deemed to be hierarchically superior to the federal government in all areas where they share competences; a regional government can overrule the central government in any dispute over the exercise of power in an area of concurrent competences (IRQ Const., arts. 114, 115). Accordingly, the Draft Constitution (art. 3) stipulates that "the Constitution and the laws of the Kurdistan Region are sovereign and supersede all laws issued by the Iraqi government outside of the exclusive jurisdiction of the Federal Authorities". However, KR Draft Cons. (art. 3 §2) goes too far by deeming itself (and other regional laws) supremacy over federal laws dealing with exclusive federal matters.

The pattern of exclusive and regional functions is an intricate one. It can be hard to see in practice, and sometimes in principle, where a regional function (e.g. maintaining internal security forces) ends and an exclusive one begins. Even if that were clear, many of the policies or initiatives of one level of government require some degree of contact with the other level. For example, while the federal government has exclusive authority over customs policy formulation, it is required to coordinate the administration of customs policy with subnational entities. In addition, reserving issues such as foreign affairs and some aspects of energy policies to the federal government has proved to be controversial, as discussed later in the paper (El-Dessouki, 2013).

It is important to mention that there are legal ambiguities in the Iraqi constitution that allow an overriding of Kurdish interests, which de-facto shows great potential for the federal government to reaffirm itself. In fact, some scholars believe that the Iraqi constitution was instrumentalized to avoid calls for independence, and by allowing for shallow rights, in fact actually undermines the Kurdish quest for statehood (Oettershagen 2015, pp. 20, 21, 26).

\section{What type of Federalism?}

The Iraqi constitution upholds a federal system in Iraq, but because of its imprecise language it is hard to say which federal model the constitution mandates. It seems the matter has been left to the political forces to settle. Yet despite the federal system enshrined in the Iraqi constitution, Iraq's political system is more like a federacy; only KRI entered into an institutionalized federal arrangement with the central government, while the rest of Iraq is not federally organized (El-Dessouki, 2013).

The GOI and KRG hold completely divergent views over the model of federalism to be adopted in Iraq. The GOI, dominated by the Shia, are in favor of territorial federalism based on the US model (with a caveat of strengthening central government) because such a model of governance would allow them to optimally 
exercise the power inherent in their majority status. In fact, the GOI favors a more centralized authority and wants a federal government with strong and wideranging powers. Former Prime Minister Nouri al-Maliki wanted to amend the Iraqi constitution to strengthen and broaden the powers of the federal government and openly stated that "the existing Constitution is not suitable for nation-building" (Muir, 2009).

On the other hand, the KRG is determined to institute some form of multinational, ethnically based federalism because that would enable the Kurds to best preserve their ethnic identity and protect their political, cultural and social existence. It also would grant them a status closer to full independence (Gunter, 2008, p. 239). For Kurdish leaders, 'a Quebec-like asymmetrical decentralization' is an ideal model, in which for most purposes the KRG acts independent of the GOI (Stansfield, 2006). The government of Canada is based on a type of administrative federalism, but in practice Quebec has secured a special status for itself that provides it the benefits of ethnic federalism. The draft constitution demands similarly significant powers in their own federal unit ${ }^{1}$ (Gunter, 2008, pp. 239-43). A particularly strong sovereignty clause was written into Article 3 that poses a clear challenge to any unbalanced federal relationship Baghdad might attempt to impose. Aside from the subject areas listed in Article 110 of the Iraqi constitution that grant primary authority to the federal government, the draft constitution and laws are more sovereign and supreme than those passed by the Iraqi government. This assertion is supported by a choice of law provision that requires Kurdish courts to follow Kurdish law in the event of a conflict with other laws. This emphasis amounts to a reverse supremacy clause (Kelley 2010, 734-735). The draft measure (art. 115) even rules out any amendment to the Iraqi constitution "if it diminishes those powers exercised" by KRI without the consent of the region's parliament and people.

The Kurds believe that strengthening central government is not living up to the constitutional promise of a diverse, multi-ethnic democracy that would accord full rights to them and redress the alleged abuses of the Saddam era (Katzman, 2010, p. 5). They threatened possible secession of KRI if this trend of centralization continued, and made it clear that they would stay committed to the new Iraq only if it was federal and democratic and only if it treated them as full partners, not as a minority to be kept pacified in a semiautonomous region (Hiltermann, 2012).

But, as the experience of September 2017 independence referendum showed, secession is a difficult and costly course. It is officially opposed by the US, a decades-old policy that seeks to avoid further inflaming the region and provoking regional powers (Cooper and Gordon,
2014, p. A1). Kurdish independence is also opposed by Iraq's regional neighbors, Turkey, Iran and 'Syria' possibly to the point of armed conflict (Shifrinson, 2006). In contrast, KRI is confronted with tempting incentives to remain part of Iraq. At its full export potential, Iraq would be one of the most oil-rich countries in the world. KRI, in theory entitled to $17 \%$ of the country's national budget, is keen to leave that door open for the future. Until recently, KRI's receipt of that money accounted for a good part of the economic boom the region is known for today (Salih, 2014; Philips, 2005, p. 8).

\section{Kurdistan Polity:}

KRI's current political system predates the approval of the draft constitution. This indigenous Kurdish political system filled the vacuum of power left behind after the withdrawal of the GOI from northern Iraq in late 1991 following creating Safe Haven zone for the Kurds there (Stansfield with Anderson, 2005). The draft measure further institutionalizes the region's polity, adopting some sort of parliamentary system (art. 1). Separation of powers language is flirted with throughout Chapter 3, but it is difficult to go too far down this road in a parliamentary system. According to Natali (2010, p. 115), the draft constitution encourages presidential rule at the expense of parliamentary rule. In practice, the KRI's polity is leaning toward presidential systems, i.e., a semi-presidential one.

Legislative power is lodged in the parliament, formally known as the Kurdish National Assembly, executive power is being shared by the president of the region and the prime minister, and judicial power is centered on a judicial assembly composed of judges drawn from the various courts. Elections for parliament are supposed to be held at least every four years. Parliament has a wide range of competencies, including health services, education and culture, internal security, the environment, natural resources, agriculture, housing, trade, industry, social affairs, transport, and tourism. According to the draft constitution (art. $53 \S 1,3$ ), KRI parliament has the right to put into effect or amend the application of Iraq-wide legislation that falls outside of the federal authorities' exclusive powers. Parliament has the power to remove the prime minister and his cabinet through a vote of no confidence by two-thirds of the members. Parliament also has the power to remove the president or vice president by majority vote if the Constitutional Court ${ }^{2}$ has accused either of a violation of their oath, a violation of the constitution, or high treason (Draft Const., art. 90, 93 § 4).

The current parliament, formed after the September 2018 election, includes a stronger opposition led by the Goran movement and more fervent debates than has previously been the case in the region (EIU, 2019, pp. 35). Despite what appears to be a representative legislature, the Kurdish Parliament still has limited 
authority and is not representative of the local populations that support reform.

The executive is strong, yet divided between a president and prime minister - who leads the majority coalition in parliament (Draft Const., Ch. 3, part 2). The president, the highest executive authority in the region, is directly elected by popular suffrage for a four-year term. Under to the draft constitution, the president is prevented from standing for a third term. Due to loopholes in the draft measure, KRI Parliament extended former president Massoud Barzani's term twice after his term of office expired in 2013. He resigned in November 2017 after a Sept. 25 referendum on independence backfired and triggered armed clashes between the Iraqi forces and Peshmerga that resulted in KRI's loss of disputed territories, including Kirkuk (EIU, 2019, p. 5).

Although the president exercises an objection power that is not quite as strong as a veto power, he does have the power to dissolve parliament, propose legislation, depose ministers, convene and lead the Ministers' Council, and issue executive decrees that have legal equivalency with parliamentary laws. His powers to declare emergencies, dispatch the military, grant amnesty, and commute death sentences (Draft Const., art. 104) are not especially distinct from those granted executives in other constitutions.

The prime minister is essentially the chief architect of the region's economy, and his council of ministers run the day to day affairs of the region, per the normal functioning of such offices. Despite the signing of the KRG Unification Agreement of 2006 between the KDP and PUK, and the ratification of KR Draft Constitution, the KRG unification process, however, is not yet complete (El-Dessouki, 2013).

The draft constitution ascertains too much power to the executive, which could result in abuse of power by the president and dependency of legislative and judiciary (Oettershagen 2015, p. 25).

Furthermore, the draft constitution organizes the KRI's 'sovereign' function relating to maintaining internal security and institutionalizes its security forces, known as the Asayesh, and its defense forces called Peshmerga (Draft Const., 2009, art. 74\$15).

However, till date, the domestic security forces are divided. Both the KDP and PUK have their own security arms, based in Erbil and Sulaymaniyah, respectively (Hadji, 2015).

The Peshmerga, or defense forces of Kurdistan is a national army in many respects (Klein, 2009, p. 27). Its total strength is likely to be between 80,000 and 100,000 professional fighters (El-Dessouki, 2013). The status of the Peshmerga forces is defined in the Iraqi constitution (art. 9, § 1, 166, § 5) in a somewhat contradictory manner. While it prohibits "the formation of military militia outside the framework of the [Iraqi] armed forces", it allows KRI to establish and run internal security forces such as police, security forces and guards. There are some discrepancies between the GOI and the KRG over funding the Peshmerga, its role and deployment (Devigne 2011, p. 58). The KRG wants the Peshmerga's salaries to be paid out of national revenue and is pushing for its budget to be incorporated into the federal budget. But the GOI has been unwilling to fund these forces. This has led to a dispute between Baghdad and Arbil, and the KRG officials accusing Baghdad of not adhering to constitutional law (Oettershagen 2015, p. 22). Except for a short period of time during the fight against ISIS 2015-2016, the GOI has refused to cooperate with the Peshmerga, denying them salaries, weapons, and training (Soderberg and Phillips, 2015, p. 20).

With much justification, Kurdish leaders regard the Peshmerga as their sole guarantors of autonomy, peace and order, and militias are deeply embedded safeguards against central government aggression (IHS, 2014). More striking, the draft constitution (art. 65§ 12) stresses that no Iraqi military forces can be based in the region without the consent of the KRI Parliament. The draft measure (art. 65§ 13) gives the president the power to deploy the Kurdish military beyond the KRI with the approval of parliament. However, the constitution is ambiguously silent on whether that deployment power extends only to other areas within Iraq or whether the president can send his forces abroad (Kelly 2010, 734).

The Peshmerga is a capable army by regional standards, and possess some heavy, and mostly old, equipment (armor, artillery, anti-tank weapons, etc.), but they don't have a huge number. They are primarily a light infantry force with a relatively small number of tanks, artillery pieces, armored vehicles, and other heavy weapons. The KRG purchased a number of advanced Russian anti-tank and anti-aircraft weapons, but these may be in short supply (Pollack, 2014). During the fight against the Islamic State militia in northern Iraq, several countries have confirmed they have been supplied arms and other military equipment to Kurdish forces (Ripley, 2014).

The Kurdish forces are well trained, wear official uniforms and have a chain of command that follows a standardized protocol.

Although the President of the region is the Commanderin-Chief of the Peshmerga (Draft Const., art. 60 §1), and there is only one Minister of Peshmerga Affairs within the KRG, these forces are controlled by the KDP and PUK. Each party's Peshmerga operates independently. The Peshmerga are still not fully unified. There are questions about where weapons go, who gets them, and whether the distribution is fair to all parties. However, the KRG herald s some progress in integrating the KDP and the PUK Peshmerga (Gompert, Kelly and Watkins 2010; Soderberg and Phillips, 2015). 


\section{Disputed Territories \& Control over Natural Resources:}

The most explosive issue between the GOI and the KRG remains the dispute over the governorate of Kirkuk and other (11 to 15$)$ disputed territories in Diyala and Nineveh governorates. Many of these areas are ethnically mixed and resource-rich, and are therefore a focus of high tension between the GOI and the KRG. Kirkuk lies at the heart of the most intractable territorial disputes. Kirkuk produces a fifth of Iraq's oil (capable of yielding as much as 600,000 barrels a day) and purportedly sits on $10-16 \%$ (nearly 9 billion barrels) of its immense proven oil reserves. The supergiant oilfield that lies under the governorate is reason enough for any faction to try to assert control over $i^{3}$, let alone the historical and political grudges (Kelly 2010, 745).

The disputed territories are recognized as such in the Iraqi constitution (art. 140), but the draft constitution (art. 2) considers them all to be part of KRI. The draft measure firmly spells out the Kurds' demands to return areas formerly considered to be part of a Kurdish national homeland, including Kirkuk, as the aspired capital of KRI (Kelly, 2010, p. 746-7).

The placement of territorial concerns at the beginning of the draft constitution (art. 2) belies the understandable obsession the Kurds have with this question. Article 3 prohibits creation of a new region within the Kurdish region - so nothing can be carved away from the Kurds (Kelly, 2010, 734).

Article 140 of the Iraqi constitution stipulated that by the end of 2007 through a three-step process of 'normalization ${ }^{4}$ ', a census, and a referendum should take place in the disputed territories to determine the will of their citizens concerning the status of these territories; in other words, whether these territories should join the KRI or remain under the auspices of the federal government in Baghdad.

However, the census, and therefore the referendum, has been delayed, and Article 140 is defunct (Wolff 2010, pp. 1373-4). In fact, voices began to be heard in Baghdad arguing that the constitutional mechanism on the disputed territories was vague, invalid and void because the deadline for its implementation has effectively passed. But despite certain opinions in Baghdad, the draft constitution of 2009 (art. 2) invokes Article 140 and Kurdish leaders are adamant and insistent on the legality of the constitutional articles, and was resolute on its implementation (Sadoon, 2017, p. 387). Up to now this has left the administrative status of Kirkuk and the other disputed areas in a state of suspended animation (Oettershagen 2015, p. 19).

Dispute over the control and development of hydrocarbon resources:

According to the draft constitution (art. 9 \$1) and the Iraqi constitution (art. 121 §3), the region has an equitable share of federal general budget, proportionate to its share of the population. KRI is theoretically entitled to $17 \%$ of the national budget. But in practice, the region receives much less than that, and the GOI has cut down on the region's allocated share, and has even ceased to make any payment to the KRG for several years over conflict on oil revenues produced in the region. This is adversely affecting the pace of development in the region and is harming the ability of the KRG to pay the salaries and allowances of employees (Ottaway and Ottaway, 2014, p.142).

Baghdad and Erbil are locked in major differences between over the control and development of hydrocarbon resources as well as the distribution of their revenues. Erbil insists that it should have the right of action concerning oil investments and production in its territory and demands a fair distribution of Iraq's oil/gas revenues (Gunter, 2008, p. 243). On the other hand, the GOI maintains that the Iraqi constitution provides the central government with control over Iraq's hydrocarbon resources, and that all profits must be centrally controlled and appropriately distributed in accordance with a national budget (El-Dessouki, 2012, pp. 6-8).

In fact, the Iraqi constitution provisions (arts. 111, 112) for wealth sharing have a degree of ambiguity, and the language has led to contention between the two parties. The Iraqi constitution states that oil and gas are owned by all Iraqis, and the federal government controls the distribution of oil and gas revenues, provided it does so in a fair manner and in proportion to the population distribution in all parts of the country. It stipulates that the central government has exclusive control over existing/present oil fields, but it leaves vague who has jurisdiction over new ones. To this day, the central government asserts its rights over both old and new oil reserves.

On the other hand, the draft constitution (art. 113) empowers the KRG to design the oil and gas policy for the region, develop KRI's hydrocarbon sector and reinvest its revenues into developing the region. The draft measure stipulates that the Iraqi constitution only permits an administrative role (export and marketing) for the GOI with regard to the existing/current fields that were in production prior to August 15, 2005 at a rate of five thousand barrels per day, while the regions and governorates have exclusive jurisdiction and control over undeveloped and new oil and gas fields that were not in commercial production as of that date. By taking one-sided steps with regard to the control and use of oil reserves in the $\mathrm{KRI}^{5}$ and the disputed territories, the draft constitution has signaled to Baghdad, and the other parties involved that it has control, or domestic sovereignty, over its region (Sadoon, 2017, p. 410).

From a legal perspective, we are confronted by two 
opposing viewpoints with respect to the proper interpretation of the Iraqi constitution's provisions on the control and use of hydrocarbon resources. Since oil and gas are expressly not included under the exclusive powers of the federal government, they are subject to the supremacy of regional law. The clear inference is that Article 112 of the Iraqi constitution covers oil and gas extracted from fields presently in production. Thus, all non-producing fields in KRI would be managed by the KRG alone. However, one might argue that the drafters, choosing to address oil and gas separately outside of the exclusive-concurrent dichotomy, did not intend regional or governorate law to supersede federal laws on oil and gas (Kelly 2010, p. 756, 758).

The fundamental disagreement between Baghdad and Erbil over the control and development of hydrocarbon resources is behind the failure to pass a national hydrocarbons law to define who controls oil and gas fields and revenues (Katzman 2010, p. 10; Sadoon, 2017, 224). That failure explains the KRG's decision to issue its own oil and gas law in August 2007, before the parliamentary approval of the draft constitution, which acts in accordance of the provisions of regional law. The Kurdish oil and gas law, declared unconstitutional by the GOI, provides for the KRG's control over its unexplored hydrocarbons resources, permitting generous production-sharing agreements (PSAs) with foreign companies (Paz, 2011, p. 40-1). Over 40 international companies (e.g. BP, Total, ExxonMobil and Chevron) have been working in the Kurdish oil sector (Ottaway and Ottaway, 2014, p. 142). The KRG oil and gas law provided for the establishment of a ministry and a nationalized company to oversee operations. This perhaps rests on the premise that the KRI operate economically as a de facto state along the lines of Taiwan already (Kelly, 2010, p. 754).

The hydrocarbon dispute extends to the PSAs already signed by the KRG with several international companies with neither input nor permission from the GOI. These agreements (more than 40) have caused a major political and legal crisis between the GOI and the KRG. The GOI regards these agreements as unconstitutional and invalid and has threatened to bar any company working in KRI from doing business in the rest of Iraq (Cocks, 2009; Markey, 2012). Baghdad maintains it had sole rights to strike oil deals. In fact, the was suspicious of Kurdish initiatives to issue licenses independently to foreign oil explorers, which could be seen as a stepping stone to Kurdish independence (Natali, 2010, p. 109).

On the other hand, the KRG insists that its PSCs are constitutional according to both the Iraqi constitution and the draft constitution and accuses Baghdad of attempting to prevent the Kurds from realizing their economic potential (Natali 2010, p. 109).

IV. Kurdistan's growing International Activism:
The practice of foreign affairs by subnational entities or regions has been coined in a multitude of different ways, most commonly paradiplomacy. Paradiplomacy refers to direct international activities by subnational actors. These activities can either be in concert with and complementary to, parallel to, or in conflict with parent state diplomacy (Duchacek, 1990; Kincaid, 1990, Criekemans, 2010).

The manifestations of the external activity of regions are often similar to the foreign policy of nation-states. Regions conduct official missions/visits abroad, engage in negotiations, sign and implement agreements with other international actors, and participate in worldwide forums and conferences. Other forms of subnational external activity include interregional cooperation and diaspora politics (Duchacek, 1990; El-Dessouki, 2018).

Although the Iraqi constitution makes foreign affairs the exclusive domain of the federal government, it remains somewhat ambiguous with respect to the international role of the regions. The constitution gives regions jurisdiction on implementing international agreements and empowers them to establish representative offices in Iraqi diplomatic missions for social, cultural and developmental affairs. This indeterminacy allows Kurdish leaders to claim a right to be involved in foreign affairs (IRQ. Const., 2005, arts. 155, § 1-15; 166, §4; 168; Doherty, 2011, p. 100).

The draft constitution (art. 8, § 1) arrogates to the KRI the power to enter into agreements with foreign entities (states or regions) on non-Article 110 subjects. This, likewise, becomes important in the context of concluding oil exploration and development contracts (Kelley 2010, 735). Signing independent agreements or protocols with regions or indeed with governments of states became a primary foreign policy objective of the KRI. The region realizes that international agreements would allow it to assert its international personality and its capacity to initiate and enter into formal relations with other international actors, including nation-states. Moreover, entering into international agreements is indicative of KR's ability to operate autonomously and is a way of promoting Kurdish interests (Sadoon, 2017; Cf. El-Dessouki, 2018).

Since 2006, the KRG has made agreements with several foreign countries (like France, Germany, South Korea, Turkey, Iran, UAE, Qatar, Lebanon, Egypt and Jordan), as well as international organizations (like UNESCO) and multinational companies, and regions such as North Ireland, and the French province of Dordogne. These agreements pertain to fields of oil and gas, trade, agriculture, tourism, education, transport, infrastructure, etc. (Sadoon, 2017, pp. 468-501).

The draft constitution (art. 8, § 2) also says the central government must obtain consent from the KRG before signing any treaties related to the KR. 
In addition, the draft constitution (art. 65 § 21) gives the KRI the right to establish special offices for the region in foreign countries. Currently, the KRI maintains 15 representative offices in a range of states across Asia, Europe, North America and Australia. These offices are physically separate from Iraqi embassies, and have functions that sometimes extend beyond the borders of the host country and cover other countries. Many of these offices act as embassies of sorts, and the KRI's representatives abroad consider themselves to be 'diplomatic envoys' (Sadoon, 2017, p. 471).

Furthermore, the draft constitution (art. 9) arrogates to the region the right to participate within Iraqi delegations involved in the deliberations of international intergovernmental organizations. It also ensures the participation of KRI in regional and international conferences and forums. In fact, Kurdish officials participate in international conferences and in multilateral negotiation schemes on a geographical or functional basis.

The Kurds, however, have bypassed constitutional strictures, identified by the Iraqi constitution and the draft constitution, concerning international involvement of the regions (El-Dessouki, 2013).

KRI's paradiplomacy is unprecedented in scope and in relationships. It has been direct and relatively autonomous; the Kurdish administration often deploys its own 'foreign service' apparatus and conducts foreign policy independent of Baghdad, in pursuit of its own objectives (Sadoon 2017, pp. 302-3, 385, p. 411, 469; Hadj, 2015, p. 526; El-Dessouki, 2012, pp. 12-3). The KRG now regularly receives world leaders, congressional delegations, and UN missions-all of which have strengthened its international recognition and legitimacy outside Iraqi borders (Natali 2010, p. 129). Gareth Stansfield (2013, p. 260) argues in his essay that KRI has already been a state-like entity that plays a major role in the international relations of the Middle East since 20056. Sadoon (2017, p. 472) concluded that KRI became an independent foreign policy actor (Sadoon 2017, p. 472).

External activism of KRI is perceived as a challenge by its parent state. Therefore, 'foreign affairs' has also become an additional source of conflict between the GOI and the KRG. Cooperation between Baghdad and Erbil in the field of foreign affairs is rare and the overriding pattern of relations is conflict. The KRG frequently complains about the lack of cooperation from the GOI, especially in the areas of policies toward neighboring countries and activities at the United Nations. The KRG also accuses the GOI of attempting to control all foreign policy (Doherty, 2015, p. 109; El-Dessouki, 2012, p. 11; El-Dessouki 2018). On the other hand, Baghdad accuses KRG of playing the international game independently and resists attempts by them to pursue an autonomous foreign policy.
Kurdistan's growing international activism, supported by the KR draft constitution, has increased Baghdad's fear that Kurdish leaders are using foreign relations as a means to secede from Iraq and to form an independent state. Baghdad has made efforts to contain Kurdish international activities, but this has further spurred the KRG's involvement in foreign affairs. In fact, one of the major motivations for the KRI's international engagement is the desire to enhance the type of intergovernmental relationship with the GOI or gain international recognition for the 'semi-state' status Kurdistan already enjoys (Klein, 2009, p, 10; ElDessouki, 2012, p. 23). Paradiplomacy is also used by KRI as an instrument of stateless nation-building, without requiring difficult constitutional changes (Aldecoa 1999).

\section{Conclusion:}

The main finding is that intergovernmental relations between the GOI and the KRG are constitutionally (i.e. from a comparative perspective of the Iraqi Constitution of 2005 and the KRI's draft constitution of 2009) conflictual and contentious. The two parties are locked in a struggle for control over land, wealth and political advantage which is further exacerbated by opposing notions of national identity.

Through constitutional mechanism, KRI seeks to assert its autonomy more strongly; this might mean constitutionalizing the Quebec principle of sovereigntyassociation within Iraq's legal system. This would be the best case scenario, i.e., to remain part of Iraq on more advantageous terms, which would essentially allow it to act as a de facto independent state with a looser confederal status within the Iraqi state. It makes the region as an autonomous state controlling its own foreign policy, borders, security, economy, and natural resources within Iraq.

The conflict against so-called Islamic State (IS) in Iraq (2013-2017) gave Kurdish leaders leverage over the GOI, but forced each other to cooperate against the common enemy (IS). The independence referendum crisis of 2017 gave the GOI leverage over the KRG, but eventually led each other to cooperate. Yet, the fundamental causes of conflict between the two parties are still unsettled.

Fortunately, after September 2017 independence referendum, the GOI and KRG recognize the dangers represented by the fragile situation of their IGR, and attempt to work out their differences and to reach a middle ground in the near future.

The draft of the Kurdish constitution would need to be amended and ratified. After all, a constitution is necessary in order for a democratic regime to be established and the only way the KRG can maximize its efficiency and apply the rule of law. The Kurdistan Constitution should promote the integration of the KRI into federal Iraq as the most viable option in the current 
global and regional context. As such, the case of KRI and its incorporation into a federal state, with vast autonomy, rights and responsibilities for the distinctive region, provides a par-excellence example to other countries. Thus, the integration of KRI as a federal region of Iraq might be the best option, for Kurds and Iraqis alike (Cf. Natali 2010; Oettershagen 2015). According to Natali (2010, p. 132), the Kurdistan Region cannot develop and prosper without remaining part of Iraq and cooperating with neighboring states.

\section{References}

Aldecoa, F., 1999. Towards Plurinational Diplomacy in the Deeper and Wider European Union (1985-2005). In: Aldecoa, F. and Keating, M. Eds., Paradiplomacy in Action: The Foreign Relations of Subnational Governments, Frank Cass, London, pp. 82-94.

Salih, C., 2014. Kurdistan Isn't About to Leave Iraq amid ISIS Fighting. Time (Aug. 6), http://time.com/3083172/iraq-kurdistan-independence/. Accessed Aug. 5, 2019.

Cooper, H., and Gordon, M. R. 2014. Iraqi Kurds Expand Autonomy as ISIS Reorders the Landscape. The New York Times.

Criekemans, D. 2010. Regional Sub-State Diplomacy from a Comparative Perspective: Quebec, Scotland, Bavaria, Catalonia, Wallonia, Flanders. The Hague Journal of Diplomacy, Vol. 5, No. 1-2, pp. 37 - 64.

Gompert, D. C., Kelly, T. K. and Watkins, J. 2010. Security in Iraq: A Framework for Analyzing Emerging Threats as U.S. Forces Leave. Santa Monica, CA: RAND National Defense Research Institute.

Phillips, D. L. 2005. Power-Sharing in Iraq. CSR NO. 6. New York, NY: Council on Foreign Relations.

de Vicuňa, R. 2015. Catalan Paradiplomacy, Secessionism and State Sovereignty. Masters. Leiden: Leiden University.

Doherty, P. 2011. Revere and Adhere: Examining the Legality of Kurdistani Diplomatic Engagement. NIMEP Insights vi (Fall).

Draft Const., 2009.

Duchacek, I. 1990. "Perforated Sovereignties: Towards a Typology of New Actors in International Relations", Michelmann, H. and Soldatos, P. (Eds.), Federalism and International Relations: the Role of Subnational Units, Clarendon Press, Oxford, pp. 47-62.

Economist Intelligence Unit Limited (EIU), Country Report 2019: Iraq, www.eiu.com (Subscribed only).

El-Dessouki, A., 2012. "Structural Contexts and Paradiplomacy of Iraqi Kurdistan”, Al Nahda, Vo. 13, No. 2.

El-Dessouki, A., 2013. "Conflictual Intergovernmental Relations in Iraq," Al-Nahda (Quarterly Journal issued by the Faculty of Economics and Political Science, Cairo University), Vol. 14, No. 2.

El-Dessouki, A. 2008. Paradiplomacy: The International Agency of Regional Governments- A Comparative Study of Some Regions. Ph.D., Cairo University.

El-Dessouki, A., 2016. "Who governs Kurdistan?”, Review of Economics and Political Science (REPS), Vol. 1, No. 1 (January 2016).

El-Dessouki, A., 2018. "Domestic Structure and Subnational Foreign Policy: An Explanatory Framework", REPS 3: 4.

Stansfield, G. with Anderson, L. 2005. "The Changing Parameters of Kurdish Statehood: Between Brussels and Baghdad", Institute of Arab \& Islamic Studies, University of Exeter, March 5.

Stansfield, G. 2006. "Divide and Heal", Prospect Magazine, No. 122, May 2006, http://www.prospectmagazine.co.uk/2006/05/divideand heal/ (accessed 21 December 2011).

IHS, "Security-Iraq", Jane's Sentinel Security Assessment The Gulf States, September 16, 2014, www. ihs.com, Subscribed only (Accessed October 2, 2014).

IRQ. Const., 2005

Jacqueline Devigne, "IraqoncilableDifferences? The Political Nature of the Peshmerga", NIMEP Insights, Vol. 6, Fall 2011

Klein, J. 2009. A Potential Kurdistan: The Quest for Statehood", The Emirates Occasional Papers, No. 73.

McGarry, J. 2005. "Canadian Lessons for Iraq', in The Future of Kurdistan in Iraq, edited by Brendan O'Leary, John McGarry, and Khaled Salih (Philadelphia: University of Pennsylvania Press, 2005).

Hiltermann, J. R. 2012. "Revenge of the Kurds: Breaking Away from Baghdad", Foreign Affairs, November/December 2012.

Katzman, K. 2010. The Kurds in Post-Saddam Iraq, CRS Reports for Congress, RS22079, October 1.

Pollack, K. M. 2014. Iraq: Understanding the ISIS Offensive Against the Kurds. Brookings, August 11, 2014, Accessed August 27, 2014, http://www.brookings.edu/blogs/iran-atsaban/posts/2014/08/11-pollack-isis-offensive-againstiraq-kurds.

Kincaid, J. 1990. Constituent Diplomacy in Federal Politics and the Nation-state: Conflict and Cooperation. In: Michelmann, H. and Soldatos, P. eds. Federalism and International Relations: The Role of Subnational Units, Clarendon Press, Oxford, pp. 54-9.

Sowell, K. 2014. Humpty Dumpty in Kurdistan. Foreign Policy, August 11, http://www.foreignpolicy.com/articles/2014/08/11/hum 
pty_dumpty_in_kurdistan_iraq_islamic_state_maliki_s unni_shiite (Accessed August 27, 2014)

Kuznetsov, A. 2015. Theory and Practice of Paradiplomacy: Subnational Governments in International Affairs, Routledge, London \& New York.

Ottaway, M. and Ottaway, D. 2014. How the Kurds Got Their Way: Economic Cooperation and the Middle East's New Borders. Foreign Affairs, Vol. 93, No. 3 (May/June 2014).

O'Sullivan, M. L. 2009. "Issues before Identity”, Washington Post, July22.

Kelly, M. J. 2010. The Kurdish Regional Constitution within the Framework of the Iraqi Federal Constitution: A Struggle for Sovereignty, Oil, Ethnic Identity, and the Prospects for a Reverse Supremacy Clause. The Kurdish Regional Constitution within the Framework of the Iraqi Federal Constitution: A Struggle for Sovereignty, Oil, Ethnic Identity, and the Prospects for a Reverse Supremacy Clause 114: 3, pp. 708-771.

Gunter, M., 2008. The Permanent and New Realities Facing the Kurdistan Regional Government: Options and Prospects, Journal of Muslim Minority Affairs, 28:2, 237-249.

Gunter, M., 2011. The Kurds Ascending: The Evolving Solution to the Kurdish Problem in Iraq and Turkey. New York: Palgrave Macmillan.

Muir, J, 2009. "Challenges remain after Iraqi Kurdish vote", BBC News, 30July 2009, http://news.bbc.co.uk/2/hi/middle_east/8176643.stm (accessed February 9, 2011).

Natali, D. (2010). The Kurdish quasi-state: development and dependency in post-gulf war Iraq. New York: Syracuse University Press.Stansfield, Gareth. 2013. "The Unravelling of the Post-First World War State System? The Kurdistan Region of Iraq and the Transformation of the Middle East." International Affairs 89 (2): 25982.

Parker, N. 2010. "Q\&A: Iraqi Kurdistan leader MassoudBarzani”, Los Angeles Times, November 11.

Bolleyer, N., McEwen, N. and Swenden, W. 2010. "The Dynamics of Intergovernmental Relations in the UK," Paper presented at the PSA Annual Conference, Edinburgh, Scotland, April 1, 2010.

Markey, P. 2012. "UPDATE 2-Iraqi Kurdistan halts oil exports over pay dispute",Reuters, 1 April 2012, http://www.reuters.com/article/2012/04/01/iraq-oil-

${ }^{1}$ Some scholars argue that the Canadian parallel should be followed by the Kurds. In Canada, the Quebecois, like the Kurds of Iraq, around one fifth of the state's population, consider themselves a distinct nation with their own culture. If applied to Iraq, the Canadian model would suggest a single federal unit including most Kurds and in which Kurds form a
kurdistanidUSL6E8F10OA20120401 (accessed April 10, 2012).

Paz, A. (2011). Oil and Political Authority: An Analysis of Relations between the Government of Iraq and the Kurdistan Regional Government. NIMEP Insights, 6.

Hadj, P. S., 2015. The Case for Kurdish Statehood in Iraq", Case Western Reserve Journal of International Law, Vol. 41, No. 2.

Sadoon, H., 2017. From Foreign Relations to Foreign Policy: Transformation of the Kurdish de Facto State into an Independent Foreign Policy Actor. Ph.D. thesis, University of Exeter.

Schweitzer, M., 2015. A Constitutional Crisis in a Land Without a Constitution: Presidential Terms and Iraqi Kurdistan. iconnectblog. Accessed August 14, 2019. http://www.iconnectblog.com/2015/11/a-constitutionalcrisis-in-a-land-without-a-constitution-presidentialterms-and-iraqi-kurdistan/

Shifrinson, J. R., 2006. The Kurds and Regional Security: An Evaluation of Development since the Iraq War (Crown Center for Middle East Studie at Brandcis University, 2006)

SIGIR (Special Inspector General for Iraq Reconstruction), Quarterly Report to the United States Congress, April 30, 2012.

Soderberg, N. and Phillips, D. 2015. Task Force Report: State-Building in Iraqi Kurdistan. New York, NY: Institute for the Study of Human Rights at Columbia University.

Wolff, S., 2010. Governing (in) Kirkuk: resolving the Status of a Disputed Territory in Post-American Iraq", International Affairs, Vol. 86, No. 6 (2010), pp. 136179.

Cocks, T. 2009. ANALYSIS-Iraqi, Kurd leaders' talks first step on bumpy road. Reuters, 5 August, http://www.reuters.com/article/joeBiden/idUSL565137 6 (accessed July 21, 2010).

Ripley, T. 2014. Coalition of the willing' goes into action in Iraq. Jane's Defence Weekly, September 18, 2014, Accessed September 28, 2014, www. ihs.com (subscribed only).

Oettershagen, V. 2015. The Instrumentalisation of Constitutional Conferments of Autonomy in Iraq's Constitution to Preclude Iraqi Kurds' Calls for Independence. Bachelor thesis. Leiden University.

strong majority. The Canadian model would allow Kurdistan to continue to be governed as a single national unit, as its leaders and people want.

Others point out the limits to the relevance of Quebec's selfgovernance movement to Kurdistan's quest for autonomy. After all, Quebec is a capitalist polity, doesn't have a history of sovereignty claims in other countries, and doesn't have an 
army of its own. Its society is not tribe-structured...etc. See: John McGarry, "Canadian Lessons for Iraq", in The Future of Kurdistan in Iraq, edited by Brendan O'Leary, John McGarry, and Khaled Salih (Philadelphia: University of Pennsylvania Press, 2005), pp. 31-7.

2 The Constitutional Court, which is specified in arts. 134 and 137 of the draft constitution, has not established yet.

${ }^{3}$ Kurdish officials recognize that even if Kirkuk becomes part of the Kurdistan Region, stipulations of the Iraqi constitution and the draft petroleum law indicate that Kirkuk's oil fields would not be part of the "yet to be discovered" oil wells that the KRG claims it can keep to itself, but rather would fall under the GOI's authority. See: Natali 2010, p. 109.

4 'Normalization' entails facilitating the right of return of expelled Kurds and Turkmen and their descendants to Kirkuk and other disputed areas, incentivizing the departure of Arabs who had settled in these areas during Saddam's reign, and changing the administrative boundaries of the disputed territories.

5 The KRI's hydrocarbon reserves are estimated to be 45 billion barrels of crude oil and 1 to 3 trillion cubic meters of natural gas reserves larger than those available in Azerbaijan or Ecuador, two influential members of OPEC (Sadoon 2017, p. 146).

${ }^{6}$ For more details on the development of IKI's international relations since the end of the Gulf War of 1991, see: (Sadoon 2017, p. 302-474). 